\title{
DOES WILDFIRE INCREASE THE RISK OF MOUNTAIN PINE BEETLES OUTBREAKS IN LODGEPOLE PINE FORESTS OF THE GREATER YeLLOWSTONE ECOSYSTEM?
}

\begin{abstract}
-

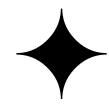

K.F. RAFFA $\uparrow$ P.A. TOWNSEND $\uparrow$ E.N. POWELL $\downarrow$ UNIVERSITY OF WISCONSIN $\uparrow$ MADISON
\end{abstract}

\begin{abstract}
$\uparrow$ ABSTRACT
We examined whether wildfire injury increased lodgepole pine, Pinus contorta, susceptibility to mountain pine beetle, Dendroctonus ponderosae, how it affects beetle reproduction, whether this interaction differs between endemic and epidemic populations, and how wildfire influences tree defense physiology. Wildfire predisposed trees to mountain pine beetle attack. In particular, fireinjured trees had a lower ability in synthesized monoterpenes in response to simulated attacks than did non-injured trees. However, beetles responded in a non-linear fashion; moderately-injured trees were most preferred. This interaction was influenced by beetle population size. Healthy and fire-injured trees were attacked when populations were high, but no healthy trees and no severely-injured trees were killed when populations were low. Beetle brood production per female was also curvilinear being highest in moderately-injured trees. This reflected a trade-off between high intraspecific competition arising from the large number of beetles needed to overcome defenses in healthy trees, and high interspecific competition and low substrate quality in severely injured trees.
\end{abstract}

These results suggest that fire-injured trees can provide a resource for mountain pine beetles during the extended periods when populations are not high enough to overcome defenses of vigorous trees. But the likelihood that populations could transition from endemic to epidemic levels due to increased tree susceptibility from wildfire is constrained by the opposing factors of lower nutritional quality and more competition load in severely-injured trees, and the relatively low incidence of moderately-injured trees. Wildfire may cause some reproductive increases in populations that are already in outbreak mode.

\section{$\uparrow \quad$ INTRODUCTION}

Conifer forests in western North America are strongly affected by wildfire and bark beetle outbreaks (Romme and Knight 1981, Veblen et al. 1994). These disturbance agents can have interacting effects, but they are not well understood. For example, wildfire injury to trees can sometimes lead to increased rates of attack by bark beetles, but this varies with beetle and tree species, and environmental conditions, (Rasmussen et al. 1996, Ryan and Amman, 1996, Wallin et al. 2003, Hood and Bentz 2007, Six and Skov 2009).

The mountain pine beetle (Dendroctonus ponderosae Hopkins) is of major concern throughout the western United States and Canada. It has recently caused extensive mortality throughout all of western North America (Hicke and Jenkins 2008, Hicke et al. 2006, Kurz et al. 2008, Safranyik et al. 2010). The primary host of the mountain pine beetle is lodgepole pine.

Mountain pine beetle adults emerge from their brood trees, fly, and select new host trees based on chemical cues. They enter the bark, mate, oviposit, and the larvae feed in the phloem. The resulting destruction of transport tissues kills the tree. Trees can defend against attack by employing constitutive and induced defenses, including rapid accumulation of toxic monoterpenes (Zulak and Bohlmann 2010). Bark beetle aggregation attract more beetles, and these mass attacks can overwhelm tree defenses (Raffa and Berryman 1983). 
Physiological stress can weaken tree defenses (Wallin and Raffa 2001, Jones et al. 2004, Kolb et al. 2007).

The question of whether burn injury increases susceptibility to mountain pine beetles has important policy implications, with regard to both formulating responses to wildfire and prescribing controlled burns. The population dynamics of treekilling bark beetles are characterized by lengthy endemic periods, during which beetles occur at very low densities and attack only a few severely stressed trees, followed by large-scale outbreak (Boone et al. 2011). We do not know whether wildfires cause beetle populations to cross the critical threshold between these phases (Raffa et al. 2008).

\section{$\uparrow \quad$ METHODS}

We sampled 16 lodgepole pine sites conducted in the Greater Yellowstone Ecosystem. Eight experienced wildfire, and eight were unburned. Four of the burned sites were within areas where mountain pine beetle was in outbreak, and four were in nonoutbreak areas. There were a total of 2056 trees. We measured attack, brood production and competitors within subsampled trees, and in pheromone-baited flight traps.

During 2010-2012, we mapped the spatial extent and intensity of bark beetle infestation (both new activity and older infestations) and the proximity of damage to fires. We partnered with the USGS and NPS to acquire SPOT $10 \mathrm{~m}$ and $5 \mathrm{~m}$ satellite imagery over most of the Greater Yellowstone Ecosystem. These images are currently being processed for two sets of analyses: 1) mapping of bark beetle damage with respect to fire locations and 2) mapping of forest vertical structure associated with long-term disturbance history and forest regeneration. The remote sensing efforts were linked to field data collected in 2010-2011.

We evaluated the defense chemistry of lodgepole pines that were uninjured or injured by wildfire. We analyzed monoterpenes by gas liquid chromatography. These measurements include both constitutive chemistry and induced chemistry in response to simulated attack.

\section{$\downarrow \quad$ RESULTS}

\section{Responses of Mountain Pine Beetle to Wildfire}

Wildfire injury strongly influenced mountain pine beetle attack on lodgepole (Powell et al. 2012). Moderately injured trees experienced the highest rates of attack. Brood production per females was also highest on moderately injured trees. Attack densities were highest on uninjured trees, which generated high intraspecific competition and lower brood production per attack. Interspecific competition was highest on severely injured trees. The major competitors were Ips, Monochamus, and Pityogenes. Populations of predators, buprestids, and turpentine beetles were low (Powell et al. 2012).

Background populations had a strong effect on mountain pine beetle attack dynamics (Powell et al. 2012). When mountain pine beetle was already in outbreak mode, uninjured trees were attacked. We did not see this at low populations.

\section{Spatial Extent and Intensity of Bark Beetle Infestation Relative to Proximity and Extent of Wildfires.}

Field data included plot-based samples of mortality, red trees, newly infested trees and unattacked trees. Because accessibility to large numbers of plots in remote areas was not feasible, we additionally developed a new method in which we used infrared and visible camera with telephoto lenses to take pictures of distant slopes. Using GPS locations, bearings and camera tilt, we precisely located the photos using Google Earth to place the actual camera shot locations on SPOT images. From 47 sets of photos, we co-located 97 positions.

\section{Lodgepole Pine Defense Chemistry}

Total concentrations of volatiles (including thirteen monoterpene hydrocarbons four allylic monoterpene alcohols, one ester and one phenyl propanoid) within constitutive phloem tissue did not vary with fire injury (Powell and Raffa 2011). But the concentrations of induced volatiles decreased by nearly half with wildfire injury. These results illustrate the importance of actively induced biochemical responses in tree defense against mountain pine beetle.

Fire injury also influenced the proportions of some volatiles in both constitutive and induced phloem tissue (Powell and Raffa 2011). Some of these alterations may relate to the behavioral mechanisms by which bark beetles detect weakened trees and communicate during mass attacks. 


\section{MANAGEMENT IMPLICATIONS}

The results of our study have implications to mountain pine beetle population dynamics, disturbance interactions, and natural resource management. Fire-injured trees appear to serve as a reservoir for bark beetles during their extended nonoutbreak population phase, when they cannot overcome the defenses of vigorous trees (Wallin et al. 2003, Powell et al. 2012).

The likelihood that population increases in fire-injured trees could trigger outbreaks, however, is reduced by increased competition and reduced substrate quality in severely-injured trees, and the lack of moderately-injured trees at the stand level (Powell et al. 2012). If an increase in population density following wildfire were to be accompanied by additional predisposing factors such as warm temperatures or drought, however, their combined effects would be more likely to favor transition to outbreaks. Wildfire could also potentially increase total beetle reproduction in stands already experiencing outbreaks.

\section{$\downarrow \quad$ CURRENT WORK}

Beginning in 2009, we have been comparing the defense chemistry and physiology of whitebark versus lodgepole pines, mountain pine beetle's relative preference for each species in the field and laboratory assays, and how predators and competitors respond to mountain pine beetles in each environment. Results to date indicate that both coevolutionary history and spatial context affect these relationships. Continuing work is extending these studies to the landscape scale, to improve our ability to incorporate chemical ecology, host selection behavior, and forest structure into management strategies.

\section{$\uparrow \quad$ ACKNOWLEDGEMENTS}

In addition to support from the UW-NPS Research Station, this project has received funding from the National Science Foundation, McIntire Stennis, and the University of Wisconsin College of Agricultural and Life Sciences. Megan Fork, Katherine Molter, Christopher Foelker, Melissa Greulich, Christopher Pennings, Andrew Long, Hillary Thompson, Jake Griffin, and Martin Simard provided valuable assistance in the field. Nicholas Keuler at the Univ. Wisconsin Statistical Consulting Lab and Jun Zhu at the Univ. Wisconsin Dept. of
Entomology provided statistical advice, Steven Krauth at the Univ. Wisconsin, Entomology Dept. and Donald Bright at Colorado State Univ., Dept. of Bioagricultural Sciences \& Pest Management provided help with insect identification, and William Romme (Colorado State Univ.), Daniel Tinker (Univ. Wyoming), and Monica Turner (Univ. Wisconsin) assisted with field site selection.

\section{LiTERATURE CITED}

Boone C, Aukema B, Bohlmann J, Carroll A, Raffa KF. 2011. Efficacy of tree defense physiology varies with herbivore population density. Canadian Journal of Forest Research. 41:1174-1188.

Hicke JA, Logan JA, Powell J, Ojima DS. 2006. Changing temperatures influence suitability for modeled mountain pine beetle (Dendroctonus ponderosae) outbreaks in the western United States. Journal of Geophysical Research - Biogeosciences. 111:G02019.

Hicke JA, Jenkins JC. 2008. Mapping lodgepole pine stand structure susceptibility to mountain pine beetle attack across the western United States. Forest Ecology and Management. 255:1536-1547.

Hood S, Bentz B. 2007. Predicting postfire Douglasfir beetle attacks and tree mortality in the northern Rocky Mountains. Canadian Journal of Forest Research. 37:1058-1069.

Jones ME, Paine TD, Fenn ME, Poth MA. 2004. Influence of ozone and nitrogen deposition on bark beetle activity under drought conditions. Forest Ecology and Management 200:67-76.

Kolb TE, Agee JK, Fule PZ, McDowell NG, Pearson K, Sala A, Waring RH. 2007. Perpetuating old ponderosa pine. Forest Ecology and Management. 249:141-157.

Kurz WA, Dymond CC, Stinson G, Rampley GL, Neilson ET, Carroll AL, Ebata T, Safranyik L. 2008. Mountain pine beetle and forest carbon feedback to climate change. Nature 452:987-990.

Powell EN, Raffa KF. 2011. Fire injury reduces inducible defenses of lodgepole pine against 
mountain pine beetle. Journal of Chemical Ecology. 37:1184-1192.

Powell EN, Townsend PA, Raffa KF. 2012. Wildfire provides refuge from local extinction but is an unlikely driver of outbreaks by mountain pine beetle. Ecological Monograms. 82:6984.

Raffa KF, Aukema BH, Erbilgin N, Klepzig KD, Wallin KF. 2005. Interactions among Conifer Terpenoids and Bark Beetles across Multiple Levels of Scale: An attempt to understand links between population patterns and physiological processes. Recent Advances in Phytochemistry. 39:80118.

Raffa KF, Berryman AA. 1983. The role of host plant-resistance in the colonization behavior and ecology of bark beetles (Coleoptera, Scolytidae). Ecological Monographs. 53:2749.

Rasmussen LA, Amman GD, Vandygriff JC, Oakes RD, Munson AS, Gibson KE. 1996. Bark beetle and wood borer infestation in the Greater Yellowstone area during four postfire years. USDA Forest Service Research Paper INT-RP-487. Ogden, UT.

Romme WH Knight DH. 1981. Fire frequency and subalpine forest succession along a topographic gradient in Wyoming. Ecology. 62:319-326.

Romme WH, Knight DH. 1982. Landscape diversity - The concept applied to Yellowstone Park. Bioscience. 32: 664-670.

Ryan KC, Amman GD. 1996. Bark beetle activity and delayed tree mortality in the Greater Yellowstone area following the 1988 fires.
In: The ecological implications of fire in Greater Yellowstone. Proceedings of the Second Biennial Conference on the Greater Yellowstone Ecosystem, Yellowstone National Park, Wyoming, USA, 19-21 September 1993. Pages 151-158.

Safranyik L, Carroll AL, Régnière J, Langor DW, Riel WG, Shore TL, Peter B, Cooke BJ, Nealis VG, Taylor SW. 2010. Potential for range expansion of mountain pine beetle into the boreal forest of North America. Canadian Entomologist. 142:415-442.

Six D, Skov K. 2009. Response of bark beetles and their natural enemies to fire and fire surrogate treatments in mixed-conifer forests in western Montana. Forest Ecology and Management. 258:761-772.

Veblen, TT, Hadley KS, Nel EM, Kitsberger T, Reid M, Villalba R. 1994. Disturbance regime and disturbance interactions in a RockyMountain sub-alpine forest. Journal of Ecology. 82:125-135.

Wallin KF, Kolb TE, Skov KR, Wagner MR. 2003. Effects of crown scorch on ponderosa pine resistance to bark beetles in northern Arizona. Environmental Entomology. 32:652-661.

Wallin KF, Raffa KF. 2001. Effects of folivory on subcortical plant defenses: Can defense theories predict interguild processes? Ecology. 82: 1387-1400.

Zulak KG, Bohlmann J. 2010. Terpenoid biosynthesis and specialized vascular cells of conifer defense. Journal of Integrated Plant Biology. 52:86-97. 